Article

\title{
Participatory Mapping of Cultural Ecosystem Services in Madrid: Insights for Landscape Planning
}

\author{
Víctor García-Díez ${ }^{\mathbb{D}}$, Marina García-Llorente and José A. González *D \\ Social-Ecological Systems Laboratory, Department of Ecology, Universidad Autónoma de Madrid, \\ 28049 Madrid, Spain; victor.garciadiez@wur.nl (V.G.-D.); marina.gllorente@uam.es (M.G.-L.) \\ * Correspondence: jose.gonzalez@uam.es; Tel.: +34-661463135
}

Received: 26 June 2020; Accepted: 23 July 2020; Published: 25 July 2020

\begin{abstract}
Cultural ecosystem services are gaining increasing attention in the scientific literature, despite the conceptual and methodological difficulties associated with their assessment. We used a participatory GIS method to map and assess three cultural ecosystem services, namely, (a) outdoor recreation, (b) aesthetic enjoyment, and (c) sense of place, in the Madrid region (Spain). The main goal of the study was to identify cultural ecosystem service hotspots in the region and to explore the relationships among the three ecosystem services mapped. We developed a Maptionnaire online questionnaire asking participants to locate places that they associate with these three ecosystem services and their main reasons for choosing those places on a map. We collected 580 complete questionnaires with 1710 location points (807 for outdoor recreation, 506 for aesthetic enjoyment and 397 for sense of place). We found that the three ecosystem services analysed were spatially correlated, with similar hotspots appearing across the region. Most of the identified hotspots were located in the northern part of the region, which is characterised by mountains and forests. Other hotspots appeared within the city of Madrid, highlighting the importance of urban green areas. Natural protected areas supplied significantly more cultural ecosystem services than non-protected areas. Among CORINE land-use types, forested areas, mountain shrubs and rocky landscapes were more relevant than arable lands for the supply of cultural ecosystem services. Our results highlight the utmost importance of including ecosystem services mapping within land-use planning and policy-making agendas to ensure the conservation of areas supplying cultural services that are critical for societal wellbeing.
\end{abstract}

Keywords: aesthetic enjoyment; cultural ecosystem services; maptionnaire; outdoor recreation; public participatory GIS (PPGIS); relational values; sense of place

\section{Introduction}

In recent years, following the creation of the Intergovernmental Platform on Biodiversity and Ecosystem Services (IPBES), the ecosystem services concept has gained great attention in the scientific and political arenas [1,2]. However, not all ecosystem services have received the same scientific weight or had the same political visibility. Cultural ecosystem services (CES) are the most complex to analyse because of their intangible character, and therefore, they are the most under-represented in ecosystem service assessment [3]. Recreational and aesthetic CES have been investigated more often than ESs in other categories, such as inspiration or sense of place [4]. In general, CES with economically measurable value have been investigated more than those without an explicit representation in conventional markets. However, the economic valuation of CES fails to connect management decisions with non-instrumental values, such as relational values linked with landscape stewardship $[5,6]$. To solve this problem, alternative non-monetary metrics, such as the spatial representation of CES through participatory mapping, have been proposed. In this way, much weight has been placed on CES over 
the last 10 years, and different authors have highlighted the importance of the consideration of these services when making land-use policy decisions $[7,8]$.

The mapping of ecosystem services is a fundamental tool for land-use planning and decisionmaking from a socio-ecological point of view [9-12]. Thus, including CES in mapping exercises has been suggested to put the ecosystem services concept into practice, making their valuation spatially explicit [9]. The difficulty of achieving this objective lies in several aspects. On one hand, cultural ecosystem services are difficult to quantify, so their evaluation and cartography are still being developed using numerous approaches [13]. On the other hand, due to the subjectivity in the appreciation of CES, wide citizen participation is necessary to include these services in territorial planning policies and ecosystem management [9].

Some projects have located and assessed the value of CES through geotagged information, such as images or posts in social media platforms [14-16]. Other approaches using participatory mapping methods (PPGIS) have also gained attention [7,17-19] since CES mapping must consider society's perceptions [9]. Using CES to uncover the intangible values associated with the human-nature relationship is of major interest to highlight the importance that relational values have for human well-being $[8,20]$.

Urbanised societies and the modern human lifestyle could reduce opportunities for human-nature interactions [21] with consequences for the visibility of CES. Urban areas foster spaces for those interactions through the promotion of home gardens and green areas [22,23]. This study was carried out in the Madrid region, which includes the third most populous city in the European Union [24]. Additionally, land use in the Madrid region has sharply changed in recent times, with urban surface areas (excluding green areas) increasing by 724\% from 1956 to 2005 [25]. Meanwhile, urban green areas increased by $175 \%$ in the last three decades, placing Madrid in the third position among European cities with the largest surface of green areas in 2018 [26].

The main goal of this study was to map three CES in the natural and semi-natural ecosystems of the Madrid region using a public participatory digital mapping tool. The mapped CES are outdoor recreation, aesthetic enjoyment, and sense of place associated with the ecosystems. The first two CES were selected due their importance for the recreation of Madrid city inhabitants. The sense of place was chosen to investigate one of the most unexplored and intangible CES which is at the same time a good indicator of human-nature connectedness through the bonds established between people, their identities and the natural environment.

Specifically, we aimed to (1) explore the geographical distribution of CES and CES hotspots, (2) analyse the relationship between the supply of CES and several geographical variables (e.g., degree of environmental protection, land-use cover, and agrarian regions) and (3) explore the motivations that drive users to select the specific locations associated with the three CES to identify the main causes that trigger people spending time in contact with nature and the contribution of CES to people's well-being. The need to understand the ways that the inhabitants of a great metropolitan area such as Madrid relate with their surrounding natural ecosystem may gain prominence in spatial planning in the following years as the populations of urban areas continue to increase.

\section{Materials and Methods}

\subsection{Study Area}

The Madrid region (Autonomous Community of Madrid) comprises an area of 8030.88 square kilometers [27] divided into 179 municipalities. The number of inhabitants in the region is increasing year after year due to the economic attractiveness of the city of Madrid and its metropolitan area of influence. Indeed, the population has increased from 4,916,426 inhabitants in 1985 to 6,663,394 in 2019 [27].

Different categories of natural protected areas exist in the Madrid region (Figure 1). These include the Sierra de Guadarrama National Park (21,714 hectares) in the northern part of the region, together with the Cuenca Alta del Manzanares Regional Park (42,583 hectares), the Parque del Sureste Regional 
Park (31,550 hectares), and the Curso Medio del río Guadarrama and its surroundings Regional Park (22,650 hectares), accompanied by another 6 areas under different protection categories (natural park, natural reserve, natural site of national interest and others), and 14 areas included in the Natura 2000 network (ZEPAs and LICs).

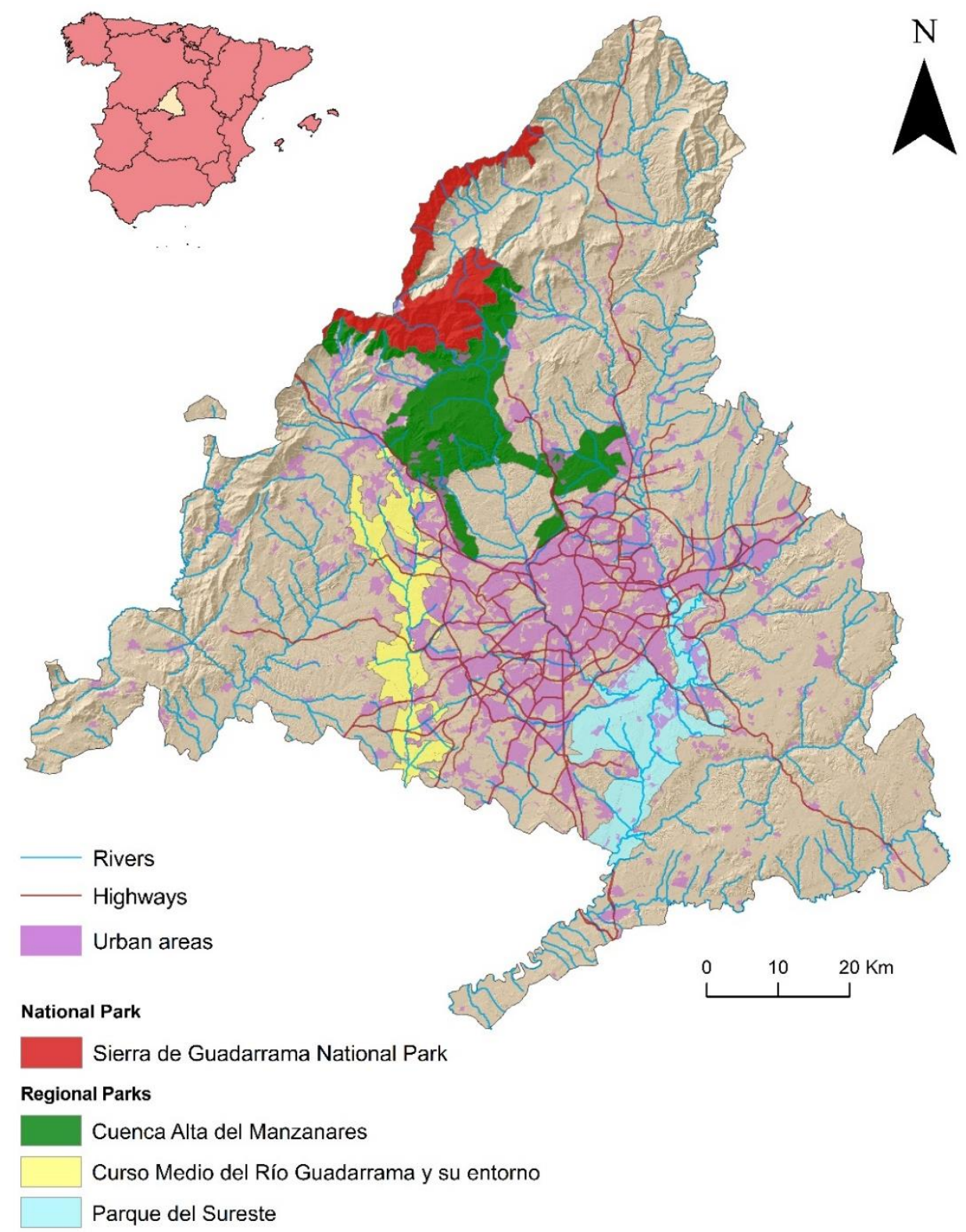

Figure 1. Autonomous Community of Madrid, showing its protected areas, urban areas, roads and rivers.

Due to the extensiveness of the study area, we are considering a territory of diverse landscapes and land uses. The study area ranges from the mountain areas located in the north and northwest, dominated by pine and oak forests, to the Las Vegas agrarian and rural district in the southeast of the Madrid region, where farms dedicated to horticultural crops, olive orchards, vineyards and cereals occupy the fluvial plains of the Tajo, Tajuña and Jarama Rivers [28]. Large areas of holm oak dehesas and the huge urban and peri-urban area of Madrid city occupy the geographic centre of the study area.

\subsection{Questionnaire Design}

A participatory mapping process based on a Maptionnaire (https://maptionnaire.com) online survey was chosen due to its effectiveness for the representation of CES [9]. The Maptionnaire tool has 
proven its utility not only for mapping CES [23] but also for its application in land management [29]. The use of public participatory tools seek to actively involve the participants in the mapping process, allowing to integrate people's perspectives into land use decision making [30]. Maptionnaire is a PPGIS tool based on a web platform on which it is possible to create and analyse interactive maps linked to questionnaires. The programme allows users to freely set points on a map and offers the possibility of relating these points to the information required through the survey.

The three CES studied were clearly explained at the beginning of the questionnaire to avoid misinterpretation by respondents. Places for outdoor recreation referred to areas that facilitate leisure and recreation activities. Places for aesthetic enjoyment referred to areas that generate an experience of enjoyment due to their scenic beauty. Finally, locations associated with sense of place were those that generate a feeling of rootedness or belonging because they represent history, cultural identity or offer opportunities to express and appreciate traditions.

The survey was structured into five main sections: (1) an introduction to the goals of the mapping exercise, clarifying that the places that could be linked to CES should be natural or semi-natural areas, excluding built infrastructure (e.g., only green areas could be chosen within cities); (2) the identification of the municipality of residence of the participant, to prevent those who were not residents of the Madrid region from completing the mapping exercise; (3) the mapping itself, where respondents were asked to locate between one and five dots per CES freely on the map to guarantee the representativeness of the sample; (4) pop-up boxes with closed-ended questions that appeared after each marker was placed asking the respondent to justify the relation of the place with the specified CES and the main reason for choosing it (Table 1); and (5) brief socio-economic questions to extend the information available on each user (age, occupation, links with nature).

Table 1. Closed-ended questions used in the survey after each dot was placed on the map by respondents.

\begin{tabular}{cc}
\hline \multicolumn{1}{c}{ Question } & \multicolumn{1}{c}{ Closed-Ended Answers } \\
\hline Does this place belong to your municipality of residence? & (1) Yes. (2) No. (3) Do not know. \\
\hline
\end{tabular}

\begin{tabular}{|c|c|}
\hline How often do you visit this place? & $\begin{array}{l}\text { (1) Daily. (2) Weekly. (3) Monthly. (4) Every year. (5) Less than } \\
\text { once a year. }\end{array}$ \\
\hline $\begin{array}{l}\text { Value the importance of this place to your personal } \\
\text { well-being. }\end{array}$ & No importance $(0$ \\
\hline \multicolumn{2}{|c|}{ Outdoor recreation: } \\
\hline How long does it take you to reach this place? & $\begin{array}{l}\text { (1) Less than } 5 \text { min. (2) Less than } 30 \text { min. (3) Less than one } \\
\text { hour. (4) One hour or more. }\end{array}$ \\
\hline What do you do at this place? & $\begin{array}{l}\text { (1) Art (painting, photography, others). (2) Meditation. (3) Pet } \\
\text { walking. (4) Flora and fauna observation. (5) Hunting/fishing. } \\
\text { (6) Biking/motor biking. (7) Mountaineering (hiking, climbing). } \\
\text { (8) Skiing. (9) Running. (10) Picnicking. (11) Other }\end{array}$ \\
\hline With whom do you visit this place? & $\begin{array}{l}\text { (1) Alone. (2) With friends. (3) With my partner. (4) With } \\
\text { family. (5) With other people. }\end{array}$ \\
\hline \multicolumn{2}{|c|}{ Aesthetic enjoyment: } \\
\hline Which are the most attractive elements of this place? & $\begin{array}{l}\text { (1) Presence of singular natural landmarks (stone monuments, } \\
\text { waterfalls, unique trees). (2) Existent flora and fauna. } \\
\text { (3) Geological formations. (4) The whole landscape. (5) The } \\
\text { anthropic elements within the natural landscape. (6) Other. }\end{array}$ \\
\hline \multicolumn{2}{|c|}{ Sense of place: } \\
\hline What is it that links you to this place? & $\begin{array}{l}\text { (1) You were born and raised here. (2) A close connection was } \\
\text { born or raised here. (3) Frequent visits. (4) Place of work. } \\
\text { (5) A remarkable experience. (6) Your personal history. } \\
\text { (7) Traditions that you admire. (8) Other. }\end{array}$ \\
\hline
\end{tabular}

\footnotetext{
${ }^{1}$ The importance for personal well-being of the different sites associated with the supply of CES was scored by participants on a scale of 0 to 100, with 0 describing a place that provides no benefit and 100 a place providing the maximum benefit.
} 


\subsection{Survey Dissemination Strategy and Scope of Sampling}

The questionnaire was open for 60 days, from 20 February to 20 April 2018. The target population was general public living in the Madrid region. Efforts were focused on contacting organisations and/or node people who would act as mass disseminators (i.e., those with established distribution networks with a significant number of people) among local inhabitants. In this way, local action groups, town councils, management bodies of protected areas and environmental and cultural associations operating at the local, regional and national levels were selected as disseminators. The project was presented to these node groups via e-mail, telephone calls and face-to-face visits (mainly to town halls). During the visits to the municipalities, posters with information on the project and instructions on how to access the questionnaire were hung up. In addition, the websites of the Social-Ecological Systems Laboratory of the Autonomous University of Madrid and the official website of the Community of Madrid Government were used to disseminate the survey.

Overall, we collected 580 complete questionnaires. The sampled population was $53 \%$ male and $47 \%$ female, with more than $75 \%$ of respondents holding university degrees. Regarding the respondents' professions, $33 \%$ were related to the service sector, $30 \%$ to the quaternary sector and $4 \%$ to the secondary and the primary sector; $23 \%$ of the respondents were students. We acknowledge a slight under-representation of participants from the primary and secondary sectors, potentially associated with their older age and lower use of web-based applications. However, the lower percentage of respondents from the primary and secondary sectors is coherent with the distribution of economic sectors in Madrid (less than $0.15 \%$ active workers in the primary sector and $14.05 \%$ at the secondary sector). At least $60 \%$ of the sample had been living in their place of residence for more than 20 years and $17 \%$ for between 10 and 20 years. Overall, $55 \%$ of the sample reported having spent a great deal of time in contact with nature during their childhood, and $24 \%$ reported spending most of their childhood in nature as they lived in rural areas (Figure 2).

\subsection{Data Analysis}

ArcGIS 10.4 software was used to manage the geographic information data. We first rasterized the three layers of the sites linked to the three CES using the "kernel density" tool (Figure 3). This tool calculates the value densities of each CES around the located points based on two pre-established parameters, the cell size and the search radius of other points. In this case, a cell size of $500 \mathrm{~m}^{2}$ and a search radius of $5000 \mathrm{~m}$ were used, following the parameters of similar investigations [31,32]. Finally, within the kernel density attribute table, a value of 0 was given to purely urban surfaces (not urban green areas) to ensure that these areas were excluded from the analysis.

Once the density maps were obtained, a random point cloud was launched on them using the "create random points" tool in ArcGIS. This tool allows for the generation of a layer of random points on the map, keeping a minimum distance between them or indicating the number of sampling points desired. For our case, we used a distance of $500 \mathrm{~m}$, which resulted in 7583 points.

All the information extracted from the density maps as well as from each environmental factor layer on the dotted grid was exported to an Excel table. This table had a column for each mapped CES (with its density values) and five other columns related to the variables used (Table 2). Then, all the points that were located on urban surfaces (except urban green areas) were deleted, leaving a total of 6554 points.

Spearman correlation tests on the three CES were carried out to assess the degree of spatial correlation between them. In addition, Kruskal-Wallis tests, with a Dunn post hoc test, were run to test whether the different environmental factors analysed influenced the provision of the three CES as well as to study the influence of each of the CES on respondents' personal well-being. All statistical analyses were performed with XLSTAT (Addinsoft). 
a) Gender

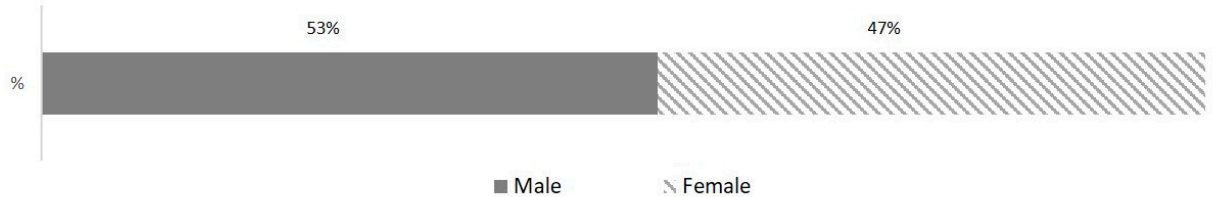

b) Education

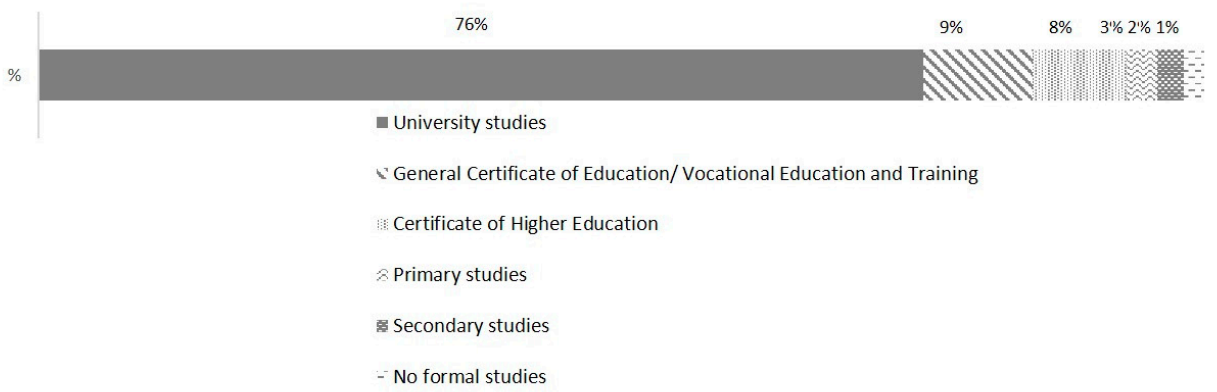

c) Profession

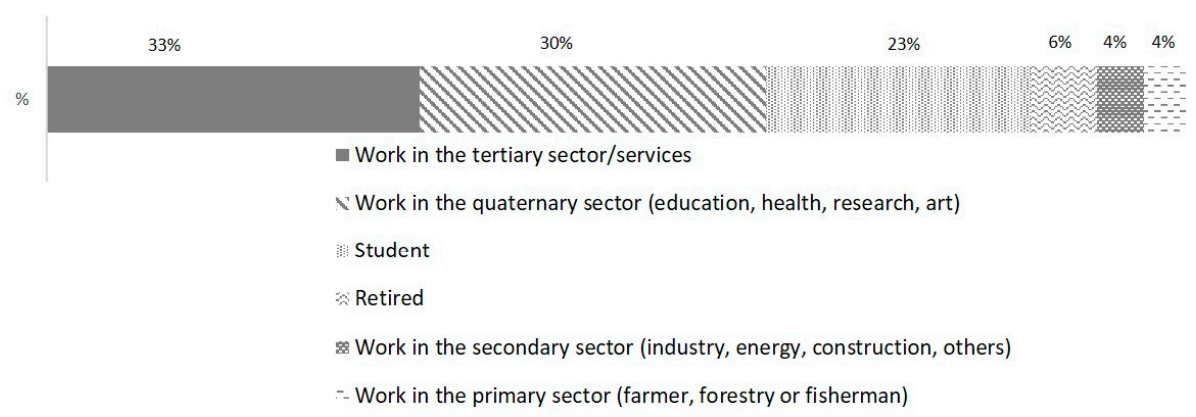

d) Time living in the place

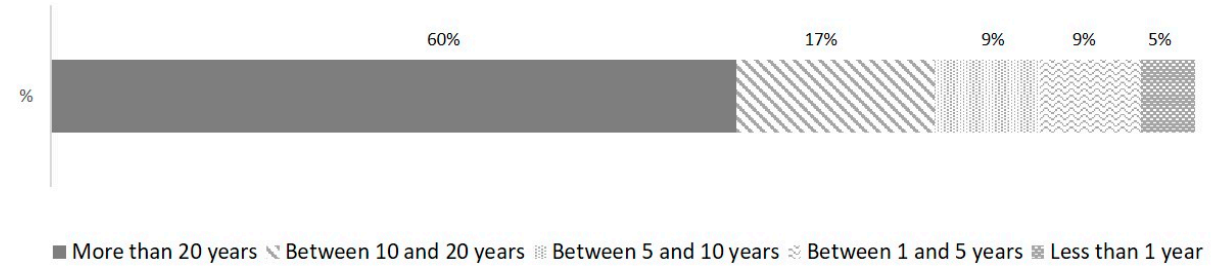

Figure 2. Socio-economic profile of participants.

Table 2. Layers generated to achieve each of the research objectives. The name of the layers is shown, along with the categories that were generated in each one of them for the statistical analyses.

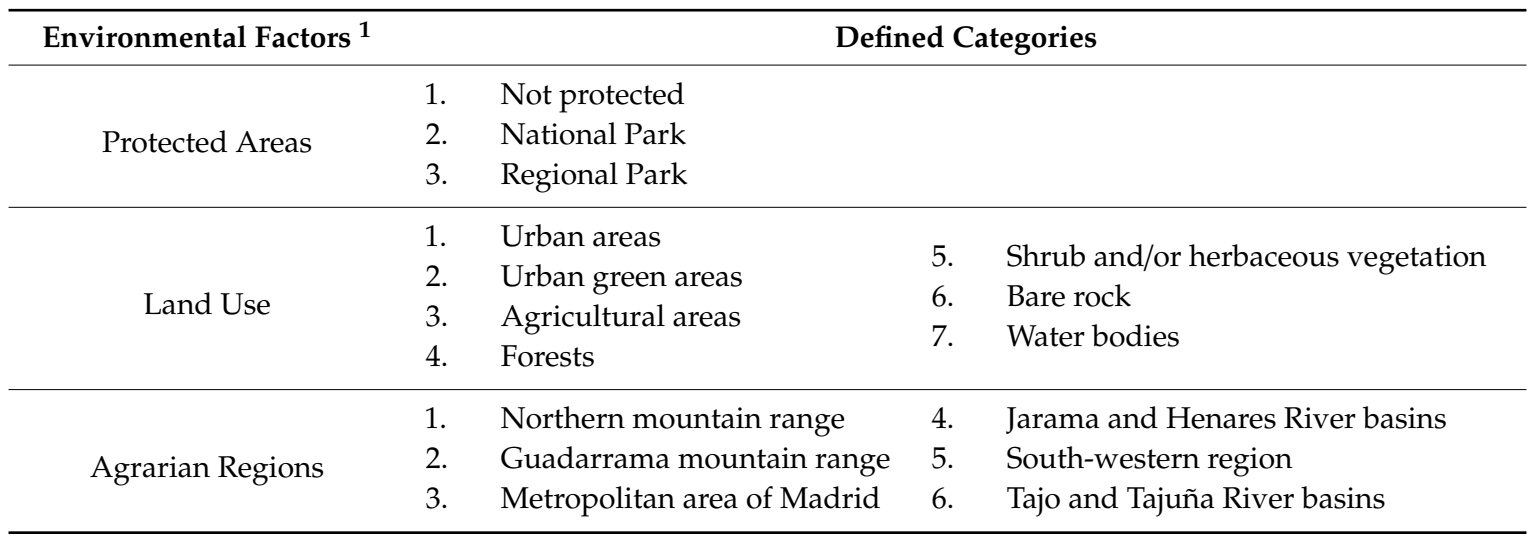

\footnotetext{
${ }^{1}$ Source of layers: Protected areas: MAPAMA. Land use: CORINE Land Cover 2012. Agrarian regions: MAPAMA.
} 
(a) Outdoor recreation

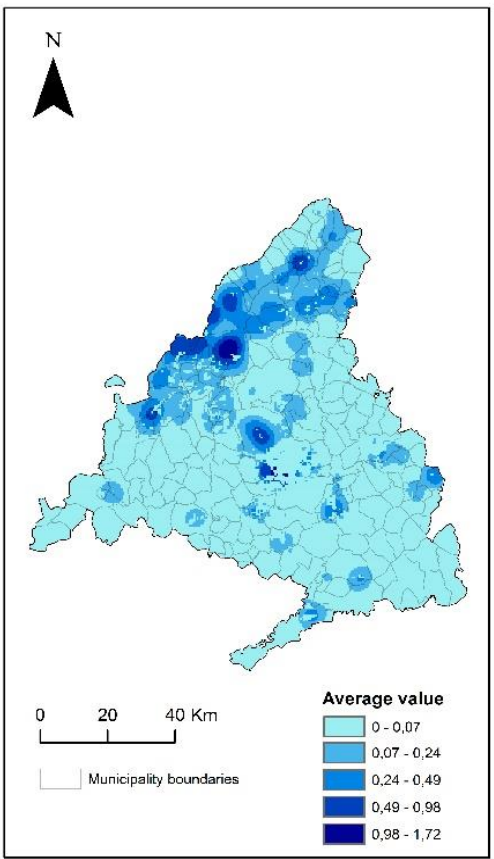

(b) Aesthetic enjoyment

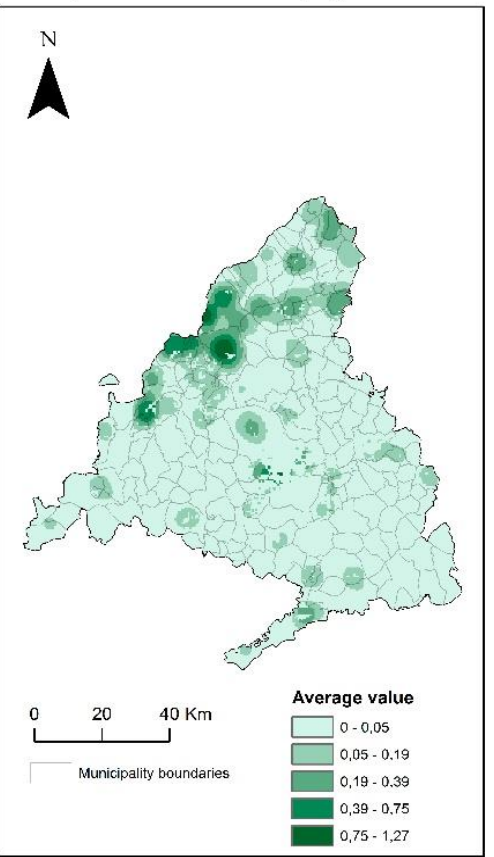

(c) Sense of place

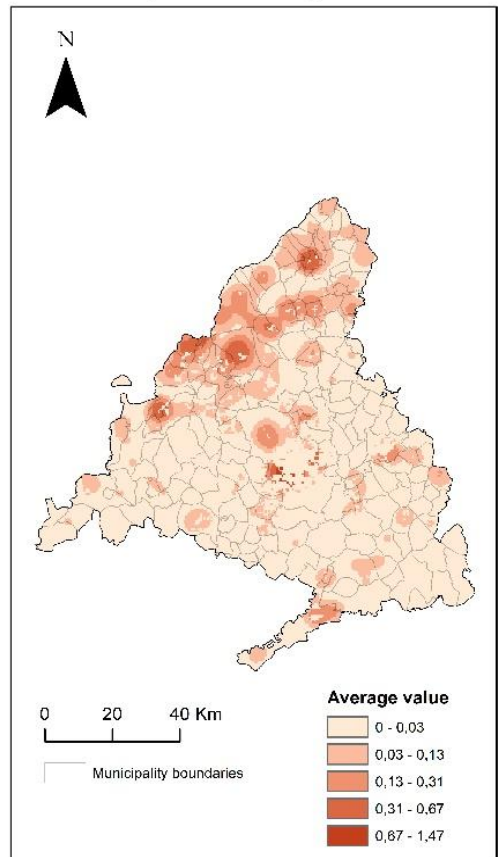

Figure 3. Graphical outputs of kernel density maps for the three cultural ecosystem services (CES).

\section{Results}

\subsection{Geographical Distribution of CES and CES Hotspots}

The total number of points located on the map and linked to the three CES was 1710. Of these, $807(47.1 \%)$ corresponded to outdoor recreation, $506(29.5 \%)$ to aesthetic enjoyment and $397(23.2 \%)$ to sense of place. Highly significant relationships were found among the three CES analysed (outdoor recreation-aesthetic enjoyment: $r_{\mathrm{S}}=0.811, p<0.01$; outdoor recreation-sense of place: $r_{\mathrm{S}}=0.786$, $p<0.01$; aesthetic enjoyment-sense of place: $\mathrm{r}_{\mathrm{s}}=0.824, p<0.01$ ).

The north/northwest area of the Madrid region, where the Guadarrama mountain range is located, stands out as the area of greatest supply of the three CES. Although the values recorded for outdoor recreation are higher than those obtained for the other two services, we found hotspots for the three CES all along the Guadarrama mountain range. In the centre of the Madrid region, the Monte del Pardo forest stands out as a highly relevant area for CES provision. Similarly, but to a lesser extent and especially for outdoor recreation, the pasturelands of the municipalities located just north of Madrid city show high CES values. In addition, the green areas located inside the city of Madrid should be highlighted as hotspots for the supply of all three CES. The southern region of Madrid is where we found the lowest supply values for the analysed CES.

\subsection{Relationship between Geographical Variables and the Supply of CES}

The degree of protection had a significant effect on the supply of the three CES (Kruskal-Wallis; outdoor recreation: $\chi^{2}=9651, p<0.01$; aesthetic enjoyment: $\chi^{2}=15,115, p<0.01$; sense of place: $\left.\chi^{2}=7898, p<0.05\right)$. For every CES, the national park obtained higher values than the regional parks and unprotected areas (Figure 4).

Similarly, significant differences were also found among the different CORINE land-use categories for the provision of CES (Kruskal-Wallis; outdoor recreation: $\chi^{2}=17,275, p<0.01$; aesthetic enjoyment: $\chi^{2}=19,820, p<0.01$; sense of place: $\left.\chi^{2}=16,379, p<0.01\right)$. Agricultural land presents significantly lower values than areas covered by forests, bare rocks and herbaceous or shrub vegetation for the three CES (Dunn tests; $p$-value < 0.05). No significant differences were found in the supply of any of the CES among different agricultural regions (Kruskal-Wallis; $p>0.05$ ). 
(a)
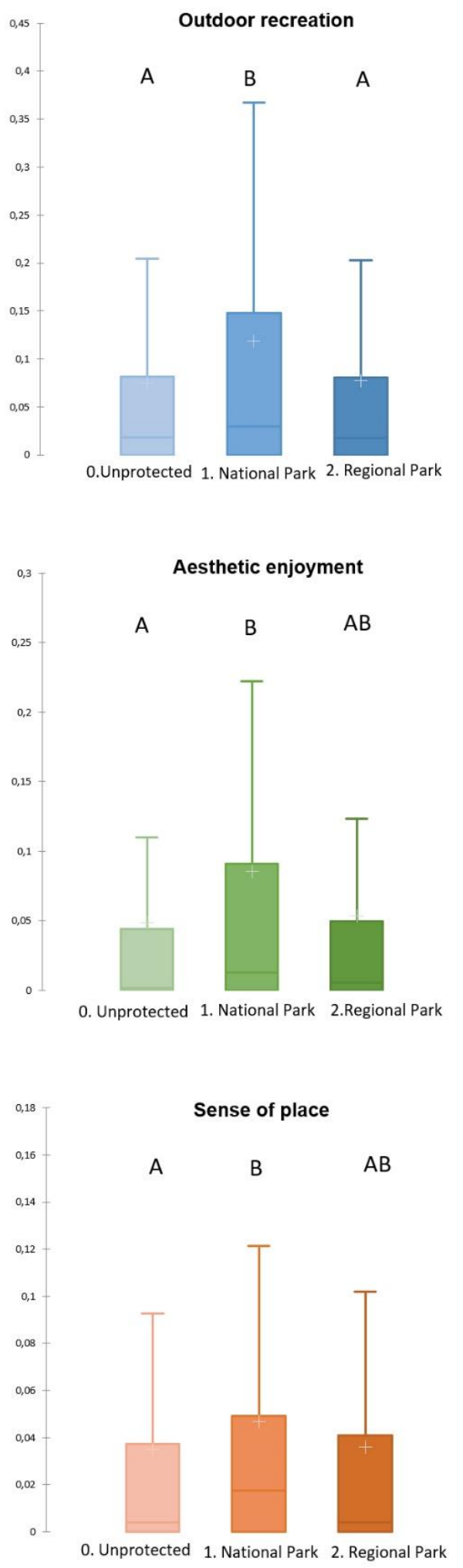

(b)

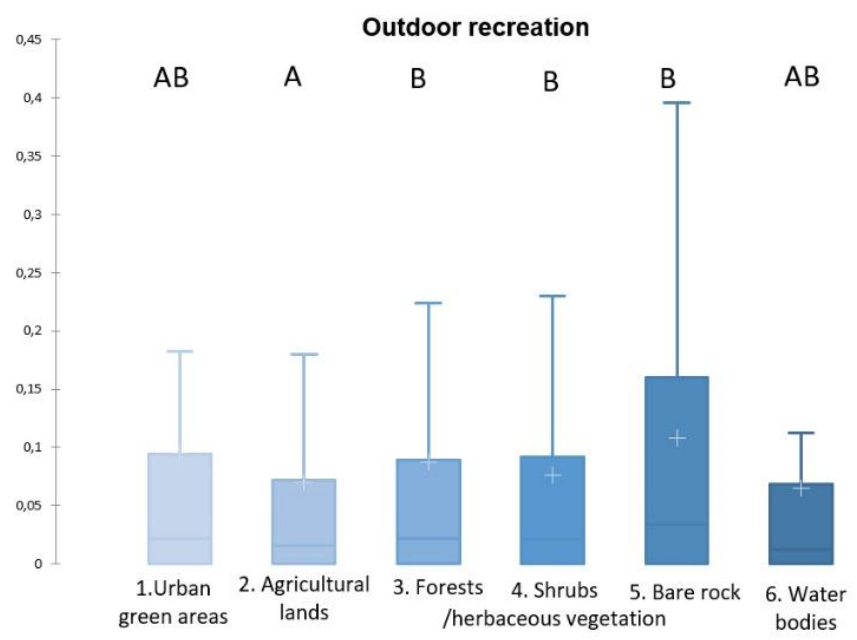

Aesthetic enjoyment
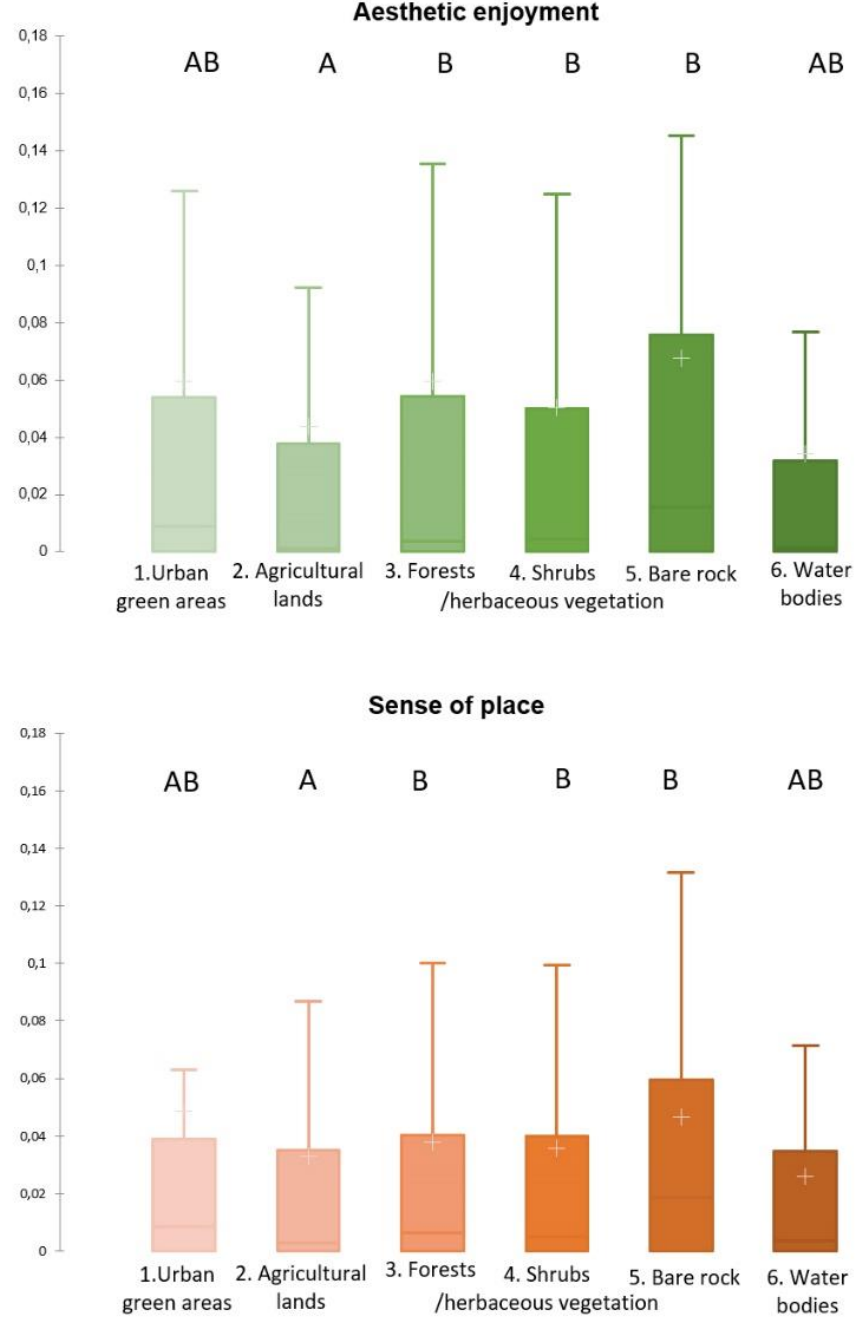

Figure 4. Relationship between the mapped supply of CES and categories of (a) natural protected areas and (b) CORINE land-use/land-cover classes. Different letters indicate significant differences (Dunn test; $p<0.05)$. 


\subsection{Respondents' Motivations for Associating Sites with CES and Well-Being}

The outdoor recreation service was mainly associated with spaces to carry out mountain-related activities (22\%), fauna and flora observation (19\%) and artistic activities (13\%) (Figure 5). When we consider these stated reasons in light of the CES map in Figure 3, it is consistent that the most valued areas are those along the mountain range. However, these reasons also apply to the values given to the Monte del Pardo forest because it is an area of great natural wealth located very close to the centre of the capital city. The same recreational activities and others such as pet walking, picnicking, running and meditation may underpin the high values registered in the urban green areas of Madrid city.

(a)

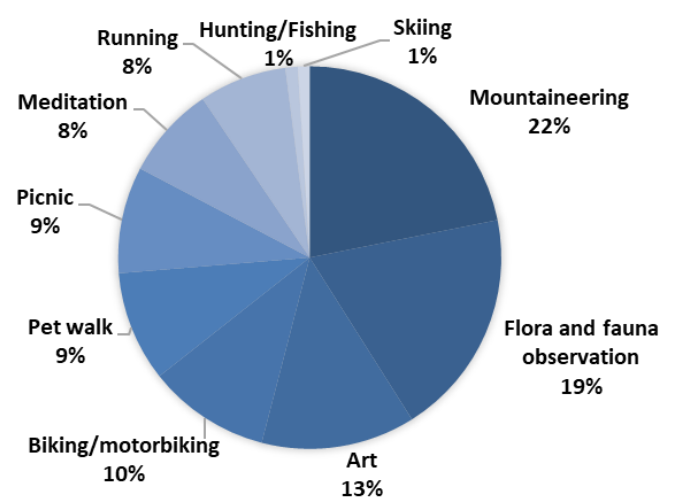

(b)

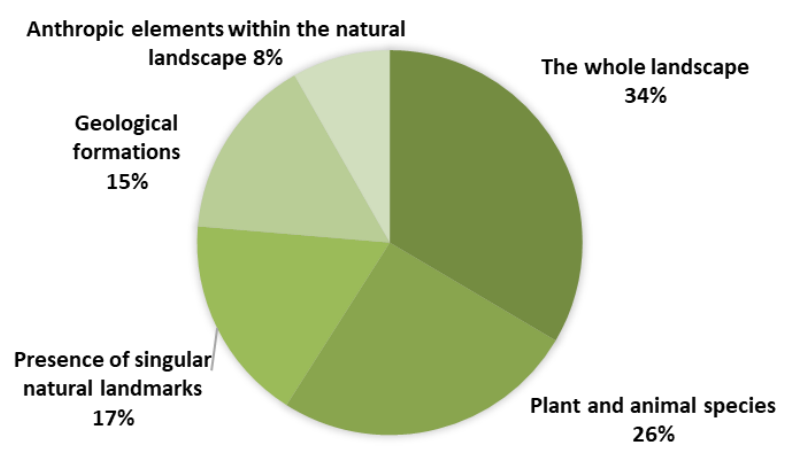

(c)

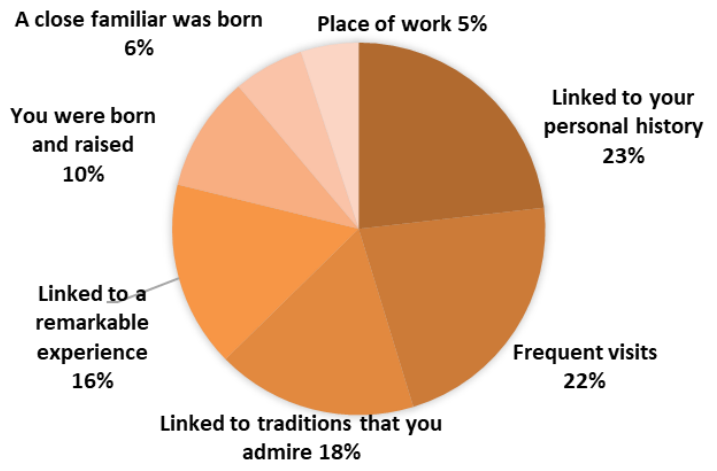

Figure 5. Pie charts depicting questionnaire users' reasons for choosing the location points for the three CES ((a) Outdoor recreation, (b) Aesthetic enjoyment, (c) Sense of place).

In terms of aesthetic enjoyment, the main reasons that participants gave for their selections were the quality of the landscape (34\%) and the plant and animal species $(26 \%)$, followed by the presence of singular natural landmarks (17\%) and geological formations (15\%). 
Finally, in the case of sense of place, locations that users associated with their personal history stand out $(23 \%)$, together with those places that they visit frequently $(22 \%)$ and places related to traditions that they value (18\%).

Regarding the perceived influence of these CES on respondents' well-being, the mean scores obtained were 84.9 over $100(\mathrm{SD}=16.0)$ for outdoor recreation, $87.0(\mathrm{SD}=15.3)$ for aesthetic enjoyment and $90.1(\mathrm{SD}=11.0)$ for sense of place. Although the three services had very high scores, significant differences were found among them (Kruskal-Wallis; $\chi^{2}=18.74, p<0.01$ ). The contribution of aesthetic enjoyment and sense of place to well-being was significantly higher than that of outdoor recreation (Dunn test; $p<0.05$ ).

\section{Discussion}

\subsection{Distribution of the Mapped CES}

Outdoor recreation was the CES most frequently mapped by participants, followed by aesthetic enjoyment and, finally, sense of place. Among the existing studies dedicated to CES mapping, the majority are focused on outdoor recreation and aesthetic enjoyment [9]. This may be due to the particular intangibility of sense of place services [28,33] and to the more specific locations where recreational activities (e.g., designated paths, greenways for cycling, etc.) or enjoyment of the beauty of the landscape (e.g., viewpoints or key elevated points with panoramic views) take place.

Despite the different numbers of points mapped for each CES, all three were distributed along the Madrid region in a very similar pattern. This is consistent with the high spatial correlation observed among the three CES in this study, which is in line with the results of previous research $[7,23,34,35]$, particularly for outdoor recreation and aesthetic enjoyment [7]. Indeed, the most intangible services (such as sense of place) are usually the least correlated with the others $[7,23]$.

It seems reasonable that the areas with the greatest value in terms of their aesthetic and landscape quality are the most frequently chosen for recreational activities in open areas (mountain-related activities, observation of flora and fauna or creative activities). This might also have a positive impact on the correlations among the three CES, since those places considered to be of greater value for aesthetic enjoyment are often those in demand for recreational and leisure activities, which in turn end up defining part of our personal identity (because we visit those places frequently and associated them with our personal history). In this way, sense of place is more linked to our experiences, life histories, and emotional lives [36]. In other words, sense of place reflects human connection to a physical place and contributes to the development of personal identity. This establishment of emotional and affective bonds with an area can take place through different channels for building human-nature connection, such as recognizing nature based on memories, perceiving nature through the senses, interacting with nature during field visits, and living in nature [37].

\subsection{Relationship between Geographical Variables and the Supply of CES}

Regarding the influence of geographical and environmental factors on the provision of CES, protected areas seem to play a central role $[19,38,39]$, as in the case of the Sierra de Guadarrama National Park in this research. The three CES were perceived significantly more frequently within this protected area than outside it. For decades, protected areas have been established without the support and inclusion of the local population, mostly based on the idea of preserving nature against human threat and restricting human activities [40]. However, according to our findings, the fact that Sierra de Guadarrama has been declared a national park has not broken its link with the population of Madrid, who still perceive it to be part of their personal identity, despite the restrictions on use that accompanied the national park declaration in 2013. This national park status guarantees the maintenance and enhancement of the sierra's natural values and landscapes (aesthetic appeal) while allowing for recreational enjoyment, which, on the other hand, has increased the number of people who visit and value it. Nonetheless, an excessive number of visitors could potentially threaten the 
provision of both aesthetic enjoyment and sense of place services [39], although this does not yet seem to be the case for the Guadarrama National Park. In summary, our results suggest that this national park status was bestowed on a territory of great cultural value for local inhabitants and has served to safeguard provision of the three CES analysed here.

The fact that forest and mountain areas have high CES values is rather widely accepted $[7,41]$. The results regarding the preferences of respondents for this type of mountain ecosystem with at least partial cover of forested vegetation over tillage areas are also consistent with those of studies carried out in other regions of Spain, such as the Basque Country [42] and Andalusia [43], as well as in other countries [44]. Complementarily, [45] recently showed the potential of geological landscapes in CES provision, which are also present in the current study in the form of the high values of bare rock land cover. These results are also consistent with those of a previous study in Madrid based on photographs published on social networks, in which scrub, forest and rocky areas, as well as mountain areas in general, appear as highly valued areas [14]. However, in our study, water bodies do not have significantly higher values than any other land-use classes, which is striking, as water bodies are often found to be important providers of CES [7,44].

In our study, the influence of the city of Madrid on the territory should not be overlooked. Valuation of CES appears to be a powerful tool in the study of the necessary reconnection between society and nature [46] — a connection that is often lost among the inhabitants of large urban centres. Our results highlight that urban inhabitants demand the CES offered by the natural areas of the mountain range as well as by the urban and peri-urban areas of Madrid. Despite the under-representation of urban systems among the ecosystem services' literature [47], urban green areas act as sites of great relevance for leisure and social relations of the inhabitants of the city $[23,48]$, which should be further explored. Moreover, in terms of frequency of visits, daily interactions with a natural place seem to be of considerable importance for appreciation of sense of place services. Thus, everyday urban green areas may have great influence on urban dwellers [49]. In this respect, sense of place is a CES highly connected with home gardens and green spaces in urban areas, especially when they are managed collectively. Sense of place has been associated with stewardship of nature; thus, people with a greater sense of place may adopt more pro-environmental actions [22].

\subsection{CES Capacity to Mediate Human-Nature Connections and Well-Being}

This assessment of the three CES underscores the importance of considering intangible interactions between nature and people to understand the relationships and the values that emerge from them. Assessing the reasons behind participants' place selection helps us understand how people relate to those places. In fact, the places chosen by participants are those that they consider themselves to have some sort of relationship with, whether it is through recreational activities or enjoyment of natural beauty or a sense of place.

Thus, CES hold a fundamental meaning or significance that goes beyond instrumental values, representing non-substitutable components of life recently associated with relational values [20]; these values are understood as encompassing all possible relationships between humans and nature, including relationships between people mediated by nature [50]. As described by [51,52], not only do these values emerge from living with nature; they are also meant to build meaningful relations and responsibilities between humans and between humans and nature. Consequently, by enhancing relational values, both social relations and support for nature conservation initiatives can be enhanced [6].

It is also worth noting the importance that participants attached to these relations with natural and semi-natural ecosystems for their personal well-being. According to [37], interactions with natural and semi-natural ecosystems have remarkable positive impacts on different aspects of human well-being as well as the intangible values that emerge from them $[8,20]$. In our case study, the high scores attributed to aesthetic enjoyment and sense of place services in relation to the contribution to personal well-being stand out. This effect may be influenced by the demand of inhabitants of urban areas such as Madrid and its outskirts for contemplative experiences of natural and semi-natural environments. In any 
case, it is striking that outdoor recreation services are the least valued in terms of their contribution to personal well-being, since outdoor recreation is the CES that has attracted the most attention within research aimed at evaluating and mapping CES [46].

\subsection{The Importance of Incorporating CES Mapping into Spatial Planning and Decision-Making}

The outstanding contribution of the CES registered in this and other studies to personal well-being [53] highlights the importance of taking CES into account in spatial planning and, specifically, in the management and proposal of protected areas [39]. Therefore, it is essential to increase efforts to evaluate and map these ecosystem services to ultimately incorporate them into the development of territorial policies [7].

Despite the difficulties found in integrating CES mapping into policy development, there are successful cases where notable progress has been made. In this regard, there are several examples from China to South Africa [9], among which a Finnish initiative involving the development of a national PPGIS software stands out [30]. In the European Union, these proposals should aim to meet the objectives of the EU Biodiversity Strategy to 2020, in which the mapping of ecosystem services is mentioned as one of the actions to be implemented by member countries [9]. Given the importance of including CES in spatial planning together with the EU's commitment, it seems essential to continue innovating methodologies for mapping ESs and especially CES, as they are currently the least represented and assessed types of ecosystem services $[5,13]$. Such mapping could enhance the visibility of relational values, which remain in the background both at the research level and in the policy discourse due to the dominance of instrumental values $[1,5]$.

Furthermore, incorporating CES into policies would have a positive effect on policy acceptance by the population [42], building bridges between those who culturally value ecosystems and those who have the authority to develop policies [54]. This would ensure the maintenance and prosperity of cultural landscapes and the practices and traditions associated with them while strengthening people's sense of connectedness and responsibility arising from their interactions with ecosystems. In addition, locating those ecosystems most valued by society facilitates the work of decision-makers in setting objectives and defining how natural resources should be managed [42].

\section{Conclusions}

Participatory mapping of outdoor recreation, aesthetic enjoyment and sense of place in the Madrid region revealed that all three CES show a high spatial correlation, although the outdoor recreation service was more frequently mapped than the others, while sense of place was the CES with the highest influence on human well-being. The northern, mountainous part of the Madrid region, together with urban and peri-urban green areas, were identified by participants as the most important areas for the supply of CES. The presence of these areas near large cities could play a fundamental role in the well-being of urban inhabitants by guaranteeing leisure and recreation in the natural environment, which in turn impacts people's personal identity.

Mountain areas, including wooded areas, rocky areas and herbaceous or scrubland vegetation, seem to be the most important suppliers of CES, with croplands and other land uses being less valued. Natural protected areas, particularly Guadarrama National Park, stand out as relevant suppliers of CES and are significantly more valued by participants than non-protected areas. Identifying relational values by means of the triggers that prompt people to connect and interact with natural and semi-natural ecosystems seems to be of great interest for CES evaluation. Participants considered the three mapped CES to be important elements contributing to their personal well-being, particularly aesthetic enjoyment through their contribution to personal identity.

Finally, our results highlight the importance of encouraging participatory mapping of CES and its application in spatial planning to ensure the maintenance of CES and their positive influence on social well-being. 
Author Contributions: Conceptualization, V.G.-D., M.G.-L. and J.A.G.; investigation, V.G.-D., M.G.-L. and J.A.G.; writing-original draft preparation, V.G.-D.; writing—review and editing, M.G.-L. and J.A.G.; supervision, M.G.-L. and J.A.G.; project administration, J.A.G.; funding acquisition, J.A.G. All authors have read and agreed to the published version of the manuscript.

Funding: This research was supported by the project ECOGRADIENTES, funded by the Spanish Ministry of Economy and Competitiveness (CGL2014-53782-P), and by funds of the European Union EU FP7 project OpenNESS (Grant agreement no. 308428), and IMIDRA research Project Assessment of Ecosystem Services provided by Agroecosystems (FP16-ECO).

Acknowledgments: The authors gratefully acknowledge Julia Fernández for their support during field surveys, and to the whole team of ECOGRADIENTES for their helpful comments on survey design. We are grateful to Alberto González for his continuous help with GIS data management. We also thank the Autonomous Community of Madrid administration and to the IMIDRA for helping us posting our questionnaire in their official websites. Finally, we are very grateful to all the municipalities of the region that participated and engaged with the project as well as with the TERRAE network and the local action groups for facilitating the contact with the municipalities.

Conflicts of Interest: The authors declare no conflict of interest.

\section{References}

1. Pascual, U.; Balvanera, P.; Díaz, S.; Pataki, G.; Roth, E.; Stenseke, M.; Watson, R.T.; Başak Dessane, E.; Islar, M.; Kelemen, E.; et al. Valuing nature's contributions to people: The IPBES approach. Curr. Opin. Environ. Sustain. 2017, 26-27, 7-16. [CrossRef]

2. Díaz, S.; Pascual, U.; Stenseke, M.; Martín-López, B.; Watson, R.T.; Molnár, Z.; Hill, R.; Chan, K.M.A.; Baste, I.A.; Brauman, K.A.; et al. Assessing nature's contributions to people. Science 2018, 359, $270-272$. [CrossRef]

3. Daniel, T.C.; Muhar, A.; Arnberger, A.; Aznar, O.; Boyd, J.W.; Chan, K.M.A.; Costanza, R.; Elmqvist, T.; Flint, C.G.; Gobster, P.H.; et al. Contributions of cultural services to the ecosystem services agenda. Proc. Natl. Acad. Sci. USA 2012, 109, 8812-8819. [CrossRef]

4. Milcu, A.I.; Hanspach, J.; Abson, D.; Fischer, J. Cultural ecosystem services: A literature review and prospects for future research. Ecol. Soc. 2013, 18. [CrossRef]

5. Ellis, E.C.; Pascual, U.; Mertz, O. Ecosystem services and nature's contribution to people: Negotiating diverse values and trade-offs in land systems. Curr. Opin. Environ. Sustain. 2019, 38, 86-94. [CrossRef]

6. Riechers, M.; Balázsi, Á.; Betz, L.; Jiren, T.S.; Fischer, J. The erosion of relational values resulting from landscape simplification. Landsc. Ecol. 2020, 1-12. [CrossRef]

7. Plieninger, T.; Dijks, S.; Oteros-Rozas, E.; Bieling, C. Assessing, mapping, and quantifying cultural ecosystem services at community level. Land Use Policy 2013, 33, 118-129. [CrossRef]

8. Kaltenborn, B.P.; Linnell, J.D.C.; Gómez-Baggethun, E. Can cultural ecosystem services contribute to satisfying basic human needs? A case study from the Lofoten archipelago, northern Norway. Appl. Geogr. 2020, 120. [CrossRef]

9. Burkhard, B.; Maes, J. (Eds.) Mapping Ecosystem Services; Pensoft Publishers: Sofia, Bulgaria, 2017.

10. Crossman, N.D.; Burkhard, B.; Nedkov, S.; Willemen, L.; Petz, K.; Palomo, I.; Drakou, E.G.; Martín-Lopez, B.; McPhearson, T.; Boyanova, K.; et al. A blueprint for mapping and modelling ecosystem services. Ecosyst. Serv. 2013, 4, 4-14. [CrossRef]

11. Egoh, B.; Rouget, M.; Reyers, B.; Knight, A.T.; Cowling, R.M.; van Jaarsveld, A.S.; Welz, A. Integrating ecosystem services into conservation assessments: A review. Ecol. Econ. 2007, 63, 714-721. [CrossRef]

12. Egoh, B.; Reyers, B.; Rouget, M.; Richardson, D.M.; Le Maitre, D.C.; van Jaarsveld, A.S. Mapping ecosystem services for planning and management. Agric. Ecosyst. Environ. 2008, 127, 135-140. [CrossRef]

13. Chan, K.M.A.; Guerry, A.D.; Balvanera, P.; Klain, S.; Satterfield, T.; Basurto, X.; Bostrom, A.; Chuenpagdee, R.; Gould, R.; Halpern, B.S.; et al. Where are Cultural and Social in Ecosystem Services? A Framework for Constructive Engagement. Bioscience 2012, 62, 744-756. [CrossRef]

14. Oteros-Rozas, E.; Martín-López, B.; Fagerholm, N.; Bieling, C.; Plieninger, T. Using social media photos to explore the relation between cultural ecosystem services and landscape features across five European sites. Ecol. Indic. 2018, 94, 74-86. [CrossRef]

15. Fisher, D.M.; Wood, S.A.; Roh, Y.-H.; Kim, C.-K. The Geographic Spread and Preferences of Tourists Revealed by User-Generated Information on Jeju Island, South Korea. Land 2019, 8, 73. [CrossRef] 
16. Karasov, O.; Heremans, S.; Külvik, M.; Domnich, A.; Chervanyov, I. On how crowdsourced data and landscape organisation metrics can facilitate the mapping of cultural ecosystem services: An Estonian case study. Land 2020, 9, 158. [CrossRef]

17. Fagerhom, N.; Käyhkö, N. Participatory mapping and geographical patterns of the social landscape values of rural communities in Zanzibar, Tanzania. Fenn. J. Geogr. 2009, 187, 43-60.

18. Nahuelhual, L.; Carmona, A.; Laterra, P.; Barrena, J.; Aguayo, M. A mapping approach to assess intangible cultural ecosystem services: The case of agriculture heritage in Southern Chile. Ecol. Indic. 2014, 40, 90-101. [CrossRef]

19. Ridding, L.E.; Redhead, J.W.; Oliver, T.H.; Schmucki, R.; McGinlay, J.; Graves, A.R.; Morris, J.; Bradbury, R.B.; King, H.; Bullock, J.M. The importance of landscape characteristics for the delivery of cultural ecosystem services. J. Environ. Manag. 2018, 206, 1145-1154. [CrossRef]

20. Himes, A.; Muraca, B. Relational values: The key to pluralistic valuation of ecosystem services. Curr. Opin. Environ. Sustain. 2018, 35, 1-7. [CrossRef]

21. Turner, W.R.; Nakamura, T.; Dinetti, M. Global Urbanization and the Separation of Humans from Nature. Bioscience 2004, 54, 585. [CrossRef]

22. Langemeyer, J.; Camps-Calvet, M.; Calvet-Mir, L.; Barthel, S.; Gómez-Baggethun, E. Stewardship of urban ecosystem services: Understanding the value(s) of urban gardens in Barcelona. Landsc. Urban Plan. 2018, 170, 79-89. [CrossRef]

23. Rall, E.; Bieling, C.; Zytynska, S.; Haase, D. Exploring city-wide patterns of cultural ecosystem service perceptions and use. Ecol. Indic. 2017, 77, 80-95. [CrossRef]

24. Eurostat. Eurostat Regional Yearbook; 2019 Edition; Eurostat: Luxembourg, 2019.

25. Comundad de Madrid. Evolución de la Ocupación del Suelo en la Comunidad de Madrid 1956-2005; Comunidad de Madrid: Madrid, Spain, 2005.

26. Alexander Castanho, R.; Cabezas, J.; Naranjo Gómez, J.M.; Martín Gallardo, J.; Fernández-Pozo, L.; Yilmaz Genç, S.; Lousada, S.; Lourdes, L. Assessing Ecosystem Services Delivered by Public Green Spaces in Major European Cities. In Landscape Architecture: Processes and Practices Towards Sustainable Development; IntechOpen Limited: London, UK, 2020; p. 13. [CrossRef]

27. Instituto de Estadística de la Comunidad de Madrid. Población total empadronada de Comunidad de Madrid; DESVAN. Banco de Datos Estructurales: Madrid, Spain, 2020.

28. Pérez-Ramírez, I.; García-Llorente, M.; Benito, A.; Castro, A.J. Exploring sense of place across cultivated lands through public participatory mapping. Landsc. Ecol. 2019, 34, 1675-1692. [CrossRef]

29. Jaligot, R.; Hasler, S.; Chenal, J. Participatory Mapping of Cultural Ecosystem Services in A Federal State: Lessons Learnt from Switzerland; ACES: Washington, DC, USA, 2018.

30. Brown, G.; Fagerholm, N. Empirical PPGIS/PGIS mapping of ecosystem services: A review and evaluation. Ecosyst. Serv. 2015, 13, 119-133. [CrossRef]

31. Alessa, L.; Kliskey, A.; Brown, G. Social-ecological hotspots mapping: A spatial approach for identifying coupled social-ecological space. Landsc. Urban Plan. 2008, 85, 27-39. [CrossRef]

32. Sherrouse, B.C.; Clement, J.M.; Semmens, D.J. A GIS application for assessing, mapping, and quantifying the social values of ecosystem services. Appl. Geogr. 2011, 31, 748-760. [CrossRef]

33. Brown, G.; Raymond, C.M.; Corcoran, J. Mapping and measuring place attachment. Appl. Geogr. 2015, 57, 42-53. [CrossRef]

34. Tilliger, B.; Rodríguez-Labajos, B.; Bustamante, J.V.; Settele, J. Disentangling values in the interrelations between cultural ecosystem services and landscape conservation-A case study of the Ifugao Rice Terraces in the Philippines. Land 2015, 4, 888-913. [CrossRef]

35. Bachi, L.; Ribeiro, S.C.; Hermes, J.; Saadi, A. Cultural Ecosystem Services (CES) in landscapes with a tourist vocation: Mapping and modeling the physical landscape components that bring benefits to people in a mountain tourist destination in southeastern Brazil. Tour. Manag. 2020, 77. [CrossRef]

36. Ives, C.D.; Abson, D.J.; von Wehrden, H.; Dorninger, C.; Klaniecki, K.; Fischer, J. Reconnecting with nature for sustainability. Sustain. Sci. 2018, 13, 1389-1397. [CrossRef]

37. Russell, R.; Guerry, A.D.; Balvanera, P.; Gould, R.K.; Basurto, X.; Chan, K.M.A.; Klain, S.; Levine, J.; Tam, J. Humans and Nature: How Knowing and Experiencing Nature Affect Well-Being. Annu. Rev. Environ. Resour. 2013, 38, 473-502. [CrossRef] 
38. Palomo, I.; Martín-López, B.; Potschin, M.; Haines-Young, R.; Montes, C. National Parks, buffer zones and surrounding lands: Mapping ecosystem service flows. Ecosyst. Serv. 2013, 4, 104-116. [CrossRef]

39. Roux, D.J.; Smith, M.K.S.; Smit, I.P.J.; Freitag, S.; Slabbert, L.; Mokhatla, M.M.; Hayes, J.; Mpapane, N.P. Cultural ecosystem services as complex outcomes of people-nature interactions in protected areas. Ecosyst. Serv. 2020, 43. [CrossRef]

40. Palomo, I.; Montes, C.; Martín-López, B.; González, J.A.; García-Llorente, M.; Alcorlo, P.; Mora, M.R.G. Incorporating the social-ecological approach in protected areas in the anthropocene. Bioscience 2014, 64, 181-191. [CrossRef]

41. Brown, G.; Brabyn, L. An analysis of the relationships between multiple values and physical landscapes at a regional scale using public participation GIS and landscape character classification. Landsc. Urban Plan. 2012, 107, 317-331. [CrossRef]

42. Peña, L.; Casado-Arzuaga, I.; Onaindia, M. Mapping recreation supply and demand using an ecological and a social evaluation approach. Ecosyst. Serv. 2015, 13, 108-118. [CrossRef]

43. García-Llorente, M.; Martín-López, B.; Iniesta-Arandia, I.; López-Santiago, C.A.; Aguilera, P.A.; Montes, C. The role of multi-functionality in social preferences toward semi-arid rural landscapes: An ecosystem service approach. Environ. Sci. Policy 2012, 19-20, 136-146. [CrossRef]

44. Brown, G. The relationship between social values for ecosystem services and global land cover: An empirical analysis. Ecosyst. Serv. 2013, 5, 58-68. [CrossRef]

45. Kubalíková, L. Cultural ecosystem services of geodiversity: A case study from Stranska skala (Brno, Czech Republic). Land 2020, 9, 105. [CrossRef]

46. Hermes, J.; Van Berkel, D.; Burkhard, B.; Plieninger, T.; Fagerholm, N.; von Haaren, C.; Albert, C. Assessment and valuation of recreational ecosystem services of landscapes. Ecosyst. Serv. 2018, 31, 289-295. [CrossRef]

47. Delgado, L.E.; Marín, V.H. Ecosystem services: Where on earth? Ecosyst. Serv. 2015, 14, 24-26. [CrossRef]

48. Calvet-Mir, L.; Gómez-Baggethun, E.; Reyes-García, V. Beyond food production: Ecosystem services provided by home gardens. A case study in Vall Fosca, Catalan Pyrenees, Northeastern Spain. Ecol. Econ. 2012, 74, 153-160. [CrossRef]

49. Colding, J.; Gren, Å.; Barthel, S. The Incremental Demise of Urban Green Spaces. Land 2020, 9, 162. [CrossRef]

50. Chan, K.M.A.; Balvanera, P.; Benessaiah, K.; Chapman, M.; Díaz, S.; Gómez-Baggethun, E.; Gould, R.; Hannahs, N.; Jax, K.; Klain, S.; et al. Why protect nature? Rethinking values and the environment. Proc. Natl. Acad. Sci. USA 2016, 113, 1462-1465. [CrossRef] [PubMed]

51. Arias-Arévalo, P.; Gómez-Baggethunb, E.; Martín-López, B.; Pérez-Rincón, M. Widening the evaluative space for ecosystem services: A taxonomy of plural values and valuation methods. Environ. Values 2018, 27, $29-53$. [CrossRef]

52. Arias-Arévalo, P.; Martín-López, B.; Gómez-Baggethun, E. Exploring intrinsic, instrumental, and relational values for sustainable management of social-ecological systems. Ecol. Soc. 2017, 22. [CrossRef]

53. Palomo, I.; Martín-López, B.; López-Santiago, C.; Montes, C. Participatory scenario planning for protected areas management under the ecosystem services framework: The Doñana social-ecological system in Southwestern Spain. Ecol. Soc. 2011, 16. [CrossRef]

54. Hirons, M.; Comberti, C.; Dunford, R. Valuing Cultural Ecosystem Services. Annu. Rev. Environ. Resour. 2016, 41, 545-574. [CrossRef]

(C) 2020 by the authors. Licensee MDPI, Basel, Switzerland. This article is an open access article distributed under the terms and conditions of the Creative Commons Attribution (CC BY) license (http://creativecommons.org/licenses/by/4.0/). 